\title{
Two new species of the genus Marengo Peckham et Peckham, 1892 (Araneae: Salticidae) from Western Ghats of India
}

\author{
Ава новых вида из рода Marengo Peckham et Peckham, 1892 \\ (Araneae: Salticidae) из Западных Гат Индии
}

\section{Puthoor Pattammal Sudhin ${ }^{1 *}$, Karunnappilli Shamsudheen Nafin ${ }^{1,2}$, Suresh P. Benjamin ${ }^{3}$, Ambalaparambil Vasu Sudhikumar ${ }^{1,4}$ П.П. Судхин ${ }^{1 *}$, К.С. Нафин ${ }^{1}$, С.П. Бенджамин ${ }^{2}$ А.В. Судхикумар ${ }^{1}$}

\author{
${ }^{1}$ Centre for Animal Taxonomy and Ecology, Department of Zoology, Christ College (Autonomous), Irinjalakuda - 680 125, Kerala, India. \\ E-mails: 2nafinks5@gmail.com, ${ }^{4}$ avsudhi@rediffmail.com \\ ${ }^{3}$ National Institute of Fundamental Studies, Hantana Road, Kandy, Sri Lanka. E-mail: suresh.benjamin@gmail.com \\ ·Corresponding author. E-mail: sudhinpp@gmail.com
}

KEY WORDS: Aranei, jumping spiders, distribution, Kerala, taxonomy, Wayanad Wildlife Sanctuary.

КЛЮЧЕВЫЕ СЛОВА: Aranei, пауки-скакунчики, распространение, Керала, таксономия, заповедник Вэйнад.

ABSTRACT. Two new jumping spiders of the genus Marengo Peckham et Peckham, 1892 from the Wayanad Wildlife Sanctuary, Western Ghats, Kerala, India - M. zebra sp.n. $\left(\mathrm{O}^{\top}+\right)$ and M. batheryensis sp.n. $\left(O^{\top}+\right)$ - are diagnosed, described and illustrated. Distribution of all the Indian Marengo species is mapped as well.

How to cite this article: Sudhin P.P., Nafin K.S., Benjamin S.P., Sudhikumar A.V. 2019. Two new species of the genus Marengo Peckham et Peckham, 1892 (Araneae: Salticidae) from Western Ghats of India // Arthropoda Selecta. Vol.28. No.3. P.435-444. doi: 10.15298/arthsel. 28.3.08

РЕЗЮМЕ. Два вида пауков-скакунчиков из рода Marengo Peckham et Peckham, 1892 из заповедника Вэйнад, Западные Гнаты, Керала, Индия - M. zebra sp.n. $\left(\bigcirc^{7} \bigcirc\right)$ и M. batheryensis sp.n. $\left(\sigma^{7}+\right)$ - диагностированы, описаны и иллюстрированы. Распространение всех индийских видов Marengo также прокартировано.

\section{Introduction}

The genus Marengo was established by Peckham \& Peckham [1892] on the basis of the generotype Marengo crassipes Peckham et Peckham, 1892 from Sri Lanka. Currently, the genus contains six valid species, of which five were described from Sri Lanka and one from Thailand [WSC, 2019]. Gupta \& Siliwal [2012] reported on a single male of $M$. crassipes from the states of Uttarakhand, which to date has been the only record of Marengo from India. In the present paper, we have described two new species, M. zebra and $M$. batheryensis, from the Wayanad Wildlife Sanctuary lying in the southern Western Ghats region, Kerala, India. The current geographic distribution of the genus in India is mapped as well.

\section{Materials and methods}

Spiders were hand-collected and preserved in 70\% ethanol. A morphological examination was undertaken under a Leica M205 C stereomicroscope. The microphotographic images were taken by means of Leica DMC4500 digital camera attached to Leica M205 C stereomicroscope, with the software package Leica Application Suite (LAS), version 4.3.0. LAS montage facility. All measurements are in $\mathrm{mm}$. Measurement data for palps and legs are as follows: total length [femur, patella, tibia, metatarsus (except palp), tarsus]. The studied specimens are deposited in the reference collection at the Centre for Animal Taxonomy and Ecology (CATE), Department of Zoology, Christ College (Autonomous), Irinjalakuda, Kerala, India.

Abbreviations used in the text and figures: ALE anterior lateral eyes, AME - anterior median eyes, cd copulatory duct, co - copulatory opening, der — damaged embolic region, do - dorsal, e - embolus, ec - embolic coil, fd - fertilization duct, $\mathrm{pl}$ - prolateral, PLE - posterior lateral eyes, PME - posterior median eyes, plv prolateral ventral, $\mathrm{rl}$ - retrolateral, RTA - retrolateral tibial apophysis, rlv - retrolateral ventral, s - spermathecae, sd - sperm duct, ts - translucent septum, $\mathrm{t}$ - tegulum, v - ventral. The terminology follows Reiskind [1969]; that for leg spination follows the format by Bossellaers \& Jocqué [2000]. 


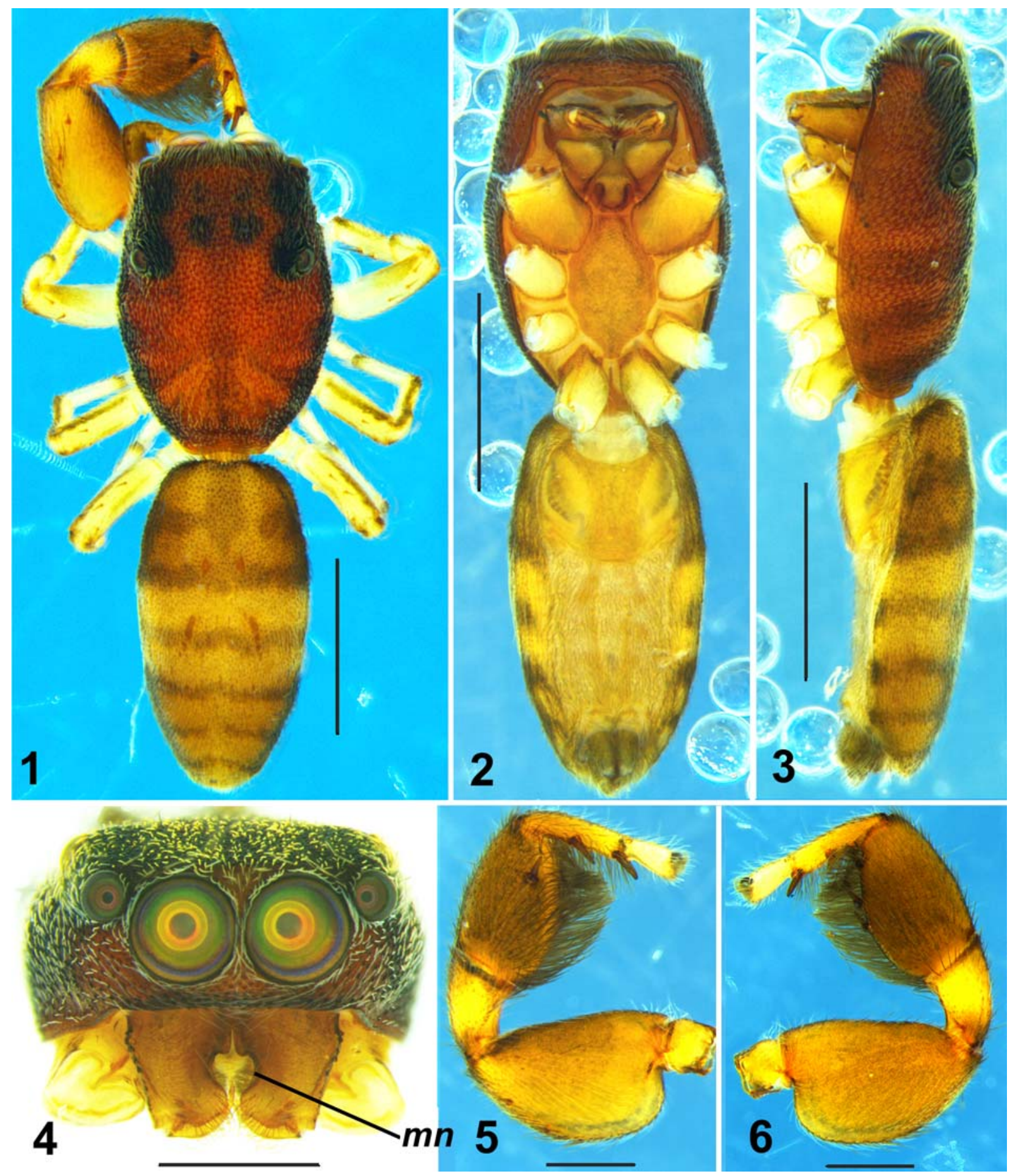

Figs 1-6. Marengo zebra sp.n., holotype male: 1 - general appearance, dorsal view; 2 - ditto, ventral view; 3 - ditto, lateral view; 4 - carapace, frontal view; 5 - left leg I, prolateral view; 6 - ditto, retrolateral view. Scale bars: $1 \mathrm{~mm}(1-3), 0.5 \mathrm{~mm}$ (4-6).

Рис. 1-6. Marengo zebra sp.n., самец-голотип: 1 - общий вид, сверху; 2 - то же, снизу; 3 - то же, сбоку; 4 - головогрудь, вид спереди; 5 - нога 1, вид спереди-сбоку; 6 - то же, вид сзади-сбоку. Масштаб: 1 мм (1-3), 0,5 мм (4-6). 

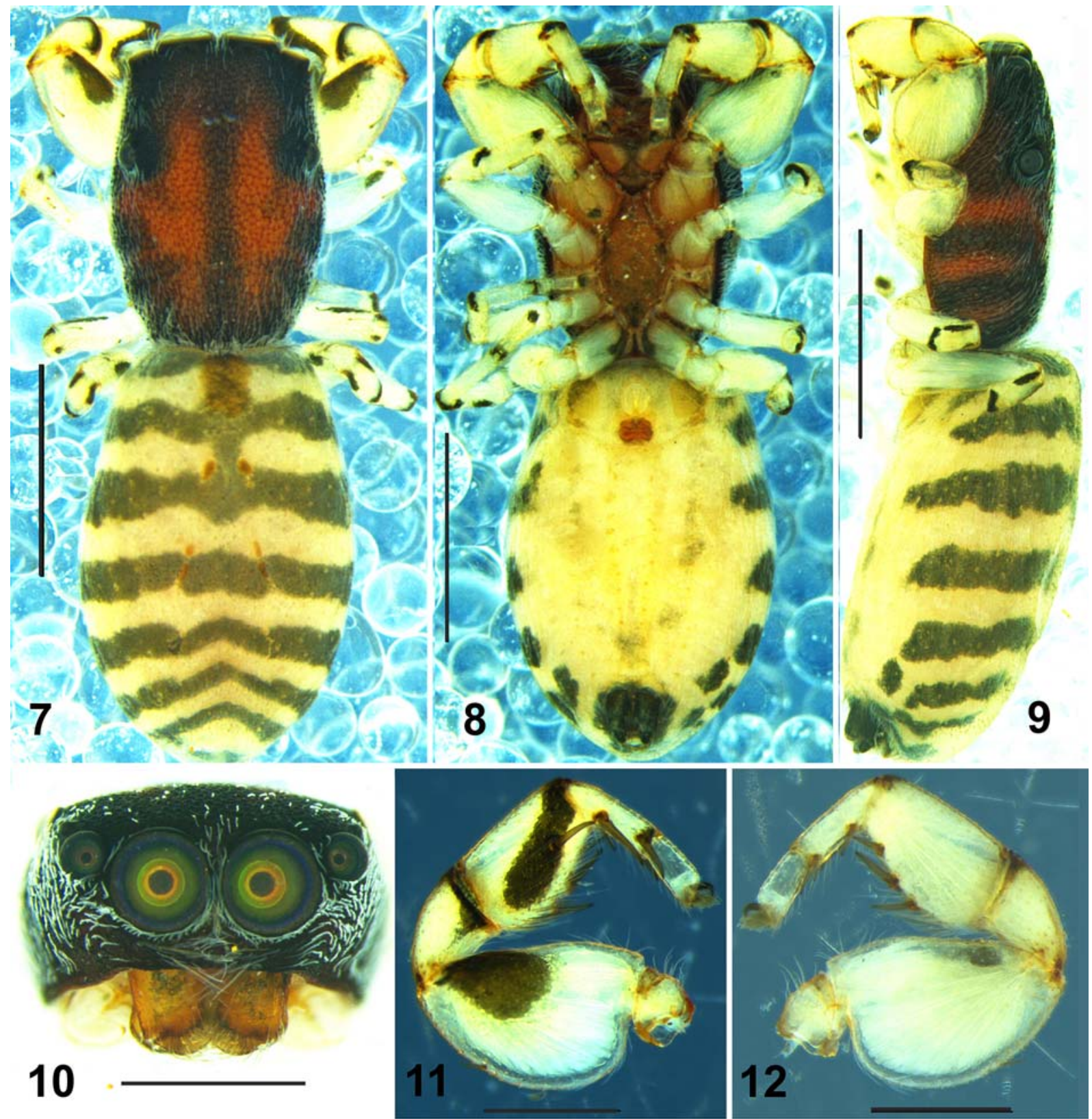

Figs 7-12. Marengo zebra sp.n., paratype female: 7 - general appearance, dorsal view; 8 - ditto, ventral view; 9 - ditto, lateral view; 10 - carapace, frontal view; 11 - left leg I, prolateral view; 12 - ditto, retrolateral view. Scale bars: $1 \mathrm{~mm}$ (7-9), 0.5 mm (10-12).

Рис. 7-12. Marengo zebra sp.n., самка-паратип: 7 - общий вид, сверху; 8 - то же, снизу; 9 - то же, сбоку; 10 - головогрудь, вид спереди; 11 - нога 1, вид спереди-сбоку; 12 - то же, вид сзади-сбоку. Масштаб: 0,2 мм (7-9), 0,1 мм (10-12).

\section{Description}

Genus Marengo Peckham et Peckham, 1892

Type species: M. crassipes Peckham et Peckham, 1892

\section{Marengo zebra sp n.}

Figs 1-17, 20-23, Map.

HOLOTYPE $\sigma^{7}$ (CATE, 8403A) from the Wayanad Wildlife Sanctuary $\left(11^{\circ} 43^{\prime} 54.5^{\prime \prime} \mathrm{N}, 76^{\circ} 20^{\prime} 18.5^{\prime \prime} \mathrm{E}\right)$, Sulthan Bathery Range, Wayanad District, Kerala, India, 896 m a.s.1., 9.11.2016, P.P. Su- dhin \& K.S. Nafin. - PARATYPES: INDIA: $20^{7} \sigma^{7}$ (CATE, $8403 \mathrm{~B})$, the same locality $\left(11^{\circ} 3^{\prime} 30.1^{\prime \prime} \mathrm{N}, 76^{\circ} 23^{\prime} 00.7^{\prime \prime} \mathrm{E}\right), 916 \mathrm{~m}$ a.s.l., 12.11.2016, P.P. Sudhin \& K.S. Nafin; $10^{7}, 1$ ㅇ (CATE, 8403C), Erumatheru, Mananthavady, Wayanad District, Kerala, India, 17.03.2018, R. Sruthi.

ETYMOLOGY. The specific name is a noun in apposition that refers to the black and white striped abdomen in both sexes.

DIAGNOSIS. The male of $M$. zebra sp.n. is most similar to those of M. crassipes and M. nitida Simon, 1900, but can be separated by the following combination of characters: the zebra-like brownish colour pattern of abdomen (almost uni- 

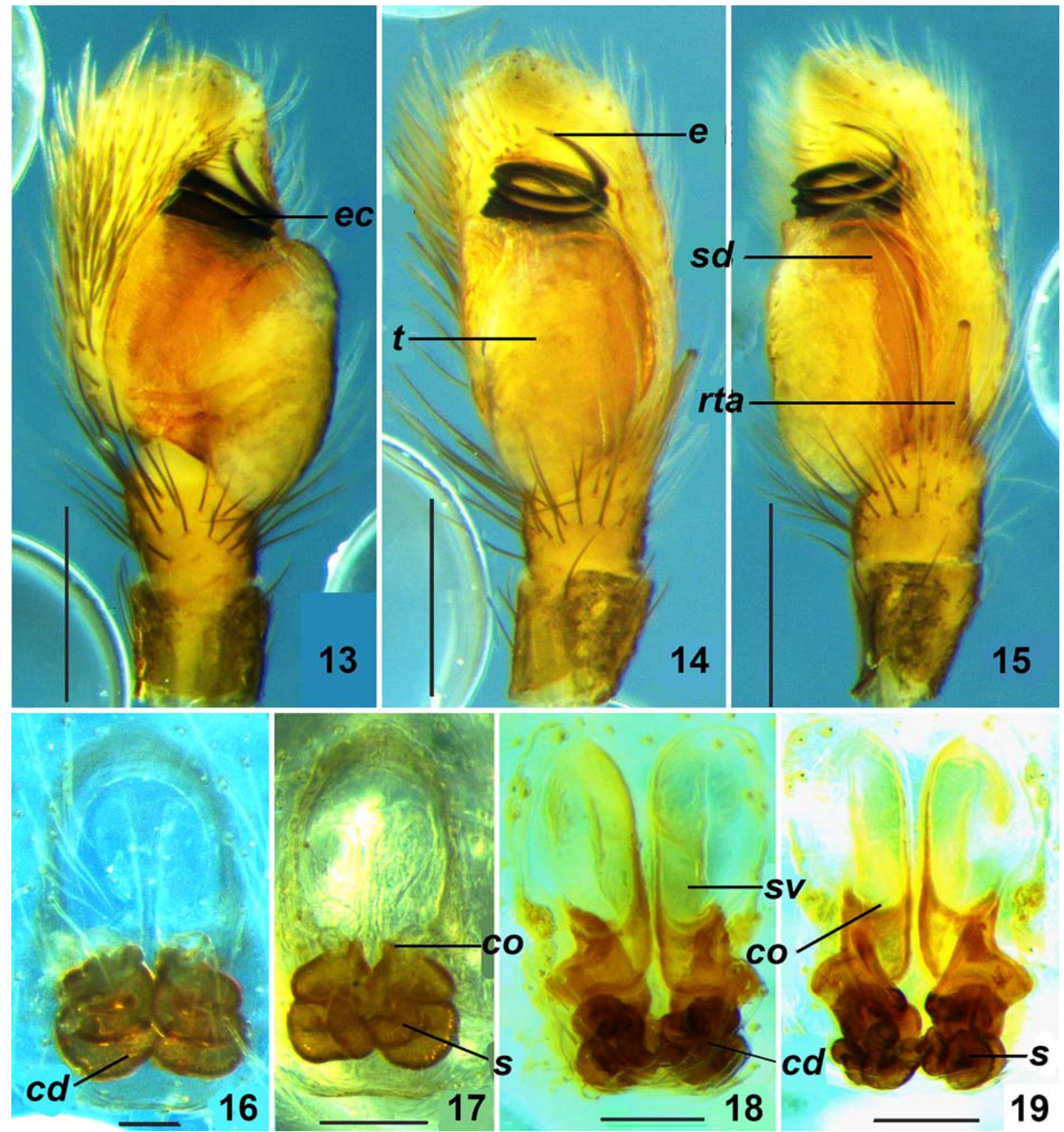

Figs 13-19. Copulatory organs of Marengo zebra sp.n. (13-17) and M. batheryensis sp.n. (18-19): 13 - left male palp, prolateral view; 14 - ditto, ventral view, 15 - ditto, retrolateral view; 16, 18 - epigyne, ventral view; 17, 19 - spermathecae, dorsal view. Scale bars: $1 \mathrm{~mm}(13-15), 0.5 \mathrm{~mm}$ (16-19). Abbreviations as explained in 'Material and methods'.

Рис. 13-19. Копулятивные органы Marengo zebra sp.n. (13-17) и M. batheryensis sp.n. (18-19): 13 - левая пальпа самца, вид спереди-сбоку; 14 - то же, вид снизу, 15 - то же, вид сзади-сбоку; 16, 18 - эпигина, вид снизу; $17,19-$ сперматека, вид сверху. Масштаб: 0,2 мм (13-15), 0,1 мм (16-19). Сокращения как объяснено в 'Материалах и методах'.

form in colour, dorsally with inconspicuous dark spots and laterally with conspicuous white oval spots in M. crassipes, and with no markings in $M$. nitida); tibia with four spines (eight in both $M$. crassipes and M. nitida); chelicera modified, with a prominent medial notch on its retrolateral side (notch is absent in both $M$. crassipes and M. nitida); RTA slender, medium-sized and anteriorly narrowing (short, stout, with a truncated tip in $M$. nitida). The female of $M$. zebra sp.n. can be distinguished from those of all other Marengo species by its zebra-like abdominal colour pattern and the epigyne with S-shaped copulatory ducts and bean-shaped spermathecae (cf. figs 1-17, 20-23 with figs 60A-C, 65A$\mathrm{F}, 67 \mathrm{~A}-\mathrm{C}$ in Benjamin [2004], figs $2 \mathrm{~A}-\mathrm{E}, 3 \mathrm{~A}-\mathrm{E}$ in Benjamin [2006], and figs 4A-F in Wanless [1978]).

DISTRIBUTION. The type locality only (Map).

DESCRIPTION. MALE (holotype; Figs 1-6, 13-15, 20-21). Measurements: body length 3.80. Carapace length 1.84 , width (at the middle) 1.22 , height at PLE 0.63. Abdo- 
men length 1.95, width (at the middle) 0.96. Ocular area length 0.75. Eye diameters: AME 0.34, ALE 0.16, PME 0.03 , PLE 0.16. Eye interdistances: PME-PME 0.84, ALEALE 0.69, PME-PLE 0.27, PLE-PLE 0.84, ALE-PME 0.09. Clypeus height 0.08 . Length of chelicera 0.36. Palp and leg measurements: palp 1.23 [0.53, 0.19, 0.11, 0.40], leg I 2.62 $[0.85,0.38,0.72,0.43,0.24]$, II 1.97 [0.64, 0.31, 0.39, 0.38, $0.25]$, III $1.76[0.57,0.23,0.34,0.37,0.25]$, IV $2.32[0.76$, $0.28,0.52,0.48,0.28]$. Leg formula: 1423. Spination. Palp: femur do 1. Legs: femur I do $1 \mathrm{pl} \mathrm{2,} \mathrm{II} \mathrm{do} 1 \mathrm{pl} 1$, II-IV rl 1, do 2, pl 1; patellae I-IV spineless; tibia I rlv 3 plv 1, II v 2, III-IV spineless; metatrsi I rlv 3 plv 3, II-IV spineless; tarsi I-IV spineless. Carapace oval, reddish brown, laterally darker, covered with white setae situated on minute elevations, with two pairs of dark patches behind the AME, anterior pair small; thoracic region with light brown striae radiating from the centre to lateral margins, carapace margin with narrow dark brown lines (Figs 1,3); eyes surrounded by dark rings, setae around the eye region longer than the rest (Fig. 1); clypeus light reddish brown, low, sub-vertical, covered with white setae (Fig. 4); chelicerae light yellowish brown, less sub-vertical, parallel, covered with white setae, chelicerae retrolateral side with a prominent medial notch, which makes significant gap in between chelicerae (Fig. 4), prolaterally with black longitudinal lines (Fig. 3), promargin with two and retromargin with four teeth; endites light yellow, with light brown hairs on their inner margins, outer margins with dark brown lines (Fig. 2). Labium light yellow, laterally with a U-shaped brown marking (Fig. 2). Sternum oval, light reddish yellow, with truncated ends and wave-like margins (Fig. 2). Abdomen oval, yellowish brown, narrowing posteriorly, with a dorsal scutum, covered with white and brown setae. Dorsum with three pairs of sigillae, widely separated transverse brownish stripes and a longitudinal band situated antero-medially (Figs 1, 3). Venter: anteriorly light yellowish, other parts light brown, covered with setae, laterally with yellow and dark brown bands that are continuations of dorsal transverse stripes (Fig 2). Spinnerets light brown, densely covered with brown setae (Figs 2, 3). Leg I yellowish brown, tibia ventrally densely covered with elongated setae (Figs 5, 6). Other leg segments light yellow (Figs $1,2)$. All legs with prolateral longitudinal black stripes on femora, patellae and tibiae. All patellae, tibiae and metatarsi dorso-distally blackening. Palp as in Figs 13-15, 20-21: cymbium light yellow, tegulum yellowish brown, other segments light brown (Figs 13-15); tibia short covered with elongated setae, RTA slender, upwardly directed and narrowing anteriorly (Figs 15, 21); cymbium oval, distally truncate with an excavated tip, densely covered with setae (Figs 13-15); tegulum yellowish brown, bilobed, projecting outwards (Figs 13-15); embolus long with pointed tip, directed at 10 o'clock position (in retrolateral view) (Figs 14, 20); embolus coils 1.5 times.

FEMALE (paratype; Figs 7-12, 16-17, 22-23). Measurements: body length 3.48 . Carapace length 1.53 , width (at the middle) 1, height at PLE 0.54. Abdomen length 1.96, width (at the middle) 1.29. Ocular area length 0.63. Eye diameters: AME 0.30, ALE 0.13, PME 0.05, PLE 0.12. Eye interdistances: PME-PME 0.72, ALE-ALE 0.59, PME-PLE 0.19, PLE-PLE 0.79, ALE-PME 0.15. Clypeus height 0.11. Length of chelicera 0.24. Palp and leg measurements: palp $0.78[0.36,0.08,0.15,0.19]$, leg I $1.76[0.61,0.26,0.44$, $0.26,0.19]$, II $1.45[0.50,0.19,0.29,0.28,0.19]$, III 1.33 $[0.48,0.16,0.22,0.26,0.21]$, IV $1.93[0.65,0.24,0.43$, $0.38,0.23]$. Leg formula: 4123 . Spination. Palp: spineless.
Legs: femur I do $1 \mathrm{pl}$ 2, II do $1 \mathrm{pl}$ 1, III-IV rl 1 do 1; patellae I-IV spineless; tibia I rlv 3 plv 1, II-IV spineless; metatarsi I rlv 2 plv 2, II-IV spineless; tarsi I-IV spineless. In all respects as the male, except as follows. Carapace darker, with a medial longitudinal black stripe extending along the entire length of the carapace, anteriorly ocular area without dark patches, thoracic region laterally with black transverse stripes (Figs 7, 9); chelicerae short, yellowish brown, without a medial notch (Fig. 10), promargin with one and retromargin with four teeth; endites light yellow, with dull white inner tips (Fig 8). Labium light brown. Sternum light reddish brown, with narrowing ends, sternal margin brown (Fig 8). Pedicel pale yellow with a pair of dorsal longitudinal brown lines. Abdomen robust, creamy white, without a dorsal scutum, covered with white setae, dorsum with seven transverse dark stripes and a medial brown patch in between the first two transverse stripes, second and third stripes medially connected by a dark band (Fig. 7). Venter creamy white, medially with a pair of light brown dotted lines, clothed with white setae (Fig. 8). Spinnerets contrastingly brown, covered with black setae (Figs 8, 9). Palp creamy white, without any markings. Leg 4 with retrolateral black markings on femur and patella. Epigyne as shown in Figs 16-17, 22-23: light yellowish, covered with white hairs (Fig 16); copulatory ducts moderately long, S-shaped, entering the spermathecae posteriorly (Figs 16-17, 22-23); spermathecae yellowish brown, bean shaped, directed upwardly (Figs 17, 23); fertilization ducts moderately long, anterolaterally oriented, located in the anterior tips of spermathecae (Figs 17, 23).

\section{Marengo batheryensis sp.n.} Figs 18-19, 24-41, Map.

HOLOTYPE 9 (CATE, 8403D) from the Wayanad Wildlife Sanctuary $\left(11^{\circ} 42^{\prime} 09.8^{\prime \prime} \mathrm{N}, 76^{\circ} 20^{\prime} 39.6^{\prime \prime} \mathrm{E}\right)$, Sulthan Bathery Range, Wayanad District, Kerala, India, $868 \mathrm{~m}$ a.s.1., 7.01.2016, P.P. Sudhin \& K.S. Nafin. - PARATYPE: INDIA: $10^{7}$ (CATE, 8403E), the same locality $\left(11^{\circ} 42^{\prime} 09.8^{\prime \prime} \mathrm{N}, 76^{\circ} 20^{\prime} 39.6^{\prime \prime} \mathrm{E}\right), 746 \mathrm{~m}$ a.s.1., 868 $m$ a.s.1., 7.01.2016, P.P. Sudhin \& K.S. Nafin.

ETYMOLOGY. The specific epithet is an adjective derived from the last name of the forest range (Sulthan Bathery) from where the type series was collected.

DIAGNOSIS. The female of M. batheryensis sp.n. is most similar to that of M. striatipes Simon, 1900, but can be distinguished from it by the following combination of characters: carapace posteriorly with a pair of white lateral spots (no prominent markings in $M$. striatipes); abdomen with three white spots forming a wide triangle at the middle (two whitish spots joined by a transverse stripe in M. striatipes); ventral tibia I and patella I with modified lanceolate setae (normal, elongated setae in $M$. crassipes); tegulum almost rectangular in shape as seen in ventral view (almost oval in M. crassipes); RTA directed disto-retrolaterad (upward in $M$. crassipes) (cf. figs 18, 19, 24-41 with figs 60A-C, 67A$\mathrm{C}$, in Benjamin [2004], and figs. 4A-F, 5 A-D in Wanless [1978]). The male can easily be separated from all the other Marengo species, except for M. striatipes, by the slender femur 1.

DISTRIBUTION. The type locality only (Map).

DESCRIPTION. MALE (paratype; Figs 27-28, 33-41). Measurements: body length 2.82. Carapace length 1.38, width (at the middle) 0.95, height at PLE 0.55. Abdomen length 1.42 , width (at the middle) 0.85 . Ocular area length 0.57 . Eye diameters: AME 0.27, ALE 0.12, PME 0.03, PLE 0.12. 


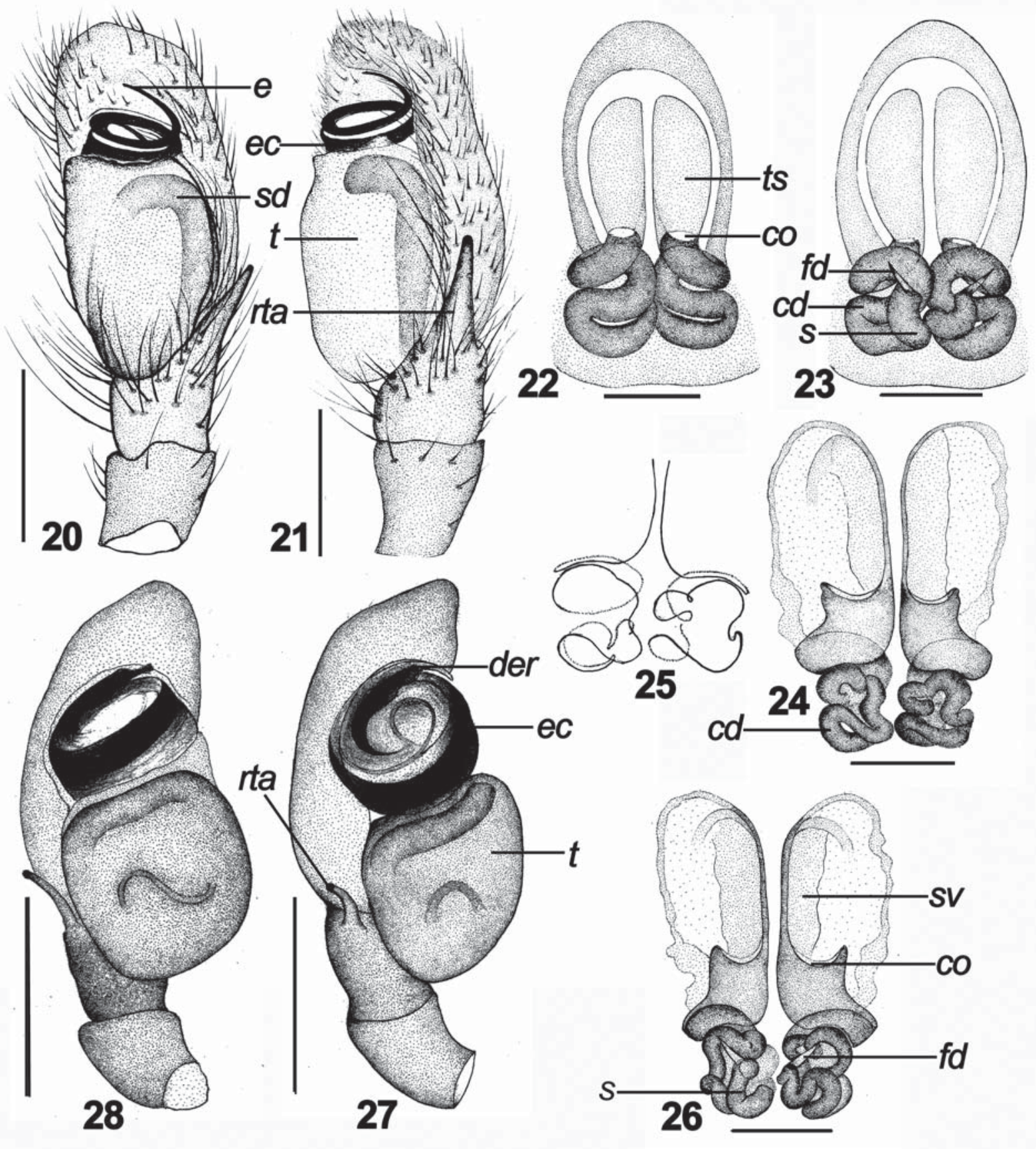

Figs 20-28. Copulatory organs of Marengo zebra sp.n. (20-23) and M. batheryensis sp.n. (24-28): 20 - male left palp, ventral view, 21 - ditto, retrolateral view; 22, 24 - epigyne, ventral view; 23, 26 - spermathecae, dorsal view; 25 - diagrammatic course of insemination ducts; 27 - right palp, retrolateral view; 28 - ditto, ventral view. Scale bars: 0.2 mm (13-15), 0.1 mm (16-19). Abbreviations as explained in 'Material and methods'.

Рис. 20-28. Копулятивные органы Marengo zebra sp.n. (20-23) и M. batheryensis sp.n. (24-28): 20 - левая пальпа самца, вид снизу, 21 - то же, виз сзади-сбоку; 22, 24 - эпигина, вид снизу; 23, 26 - сперматека, вид сверху; 25 - схематическое изображение оплодотворительных канальцев; 27 — правая пальпа самца, вид сзади-сбоку; 28 - то же, вид снизу. Масштаб: 0,2 мм (13-15), 0,1 мм (16-19). Сокращения как объяснено в 'Материалах и методах'.

Eye interdistances: PME-PME 0.55, ALE-ALE 0.52, PMEPLE 0.21, PLE-PLE 0.60, ALE-PME 0.11. Clypeus height 0.09. Length of chelicera 0.27 . Palp and leg measurements: palp $1.07[0.42,0.13,0.12,0.40]$, leg I $3.25[0.92,0.40$, $0.88,0.76,0.29]$, II $1.90[0.64,0.24,0.43,0.36,0.23]$, III $1.58[0.46,0.18,0.33,0.35,0.26]$, IV $2.07[0.66,0.26$,
$0.50,0.39,0.26]$. Leg formula: 1423 . Spination. Palp: femur do 1. Legs: femur I-IV pl 1; patellae I-IV spineless; tibia I rlv 3 plv 3, II-IV spineless; metatarsi I rlv 3 plv 3, II-IV spineless; tarsi I-IV spineless. In all respects as the female, except as follows. Carapace, dark reddish brown, slightly elongate and robust, with distinct dark patches just behind 


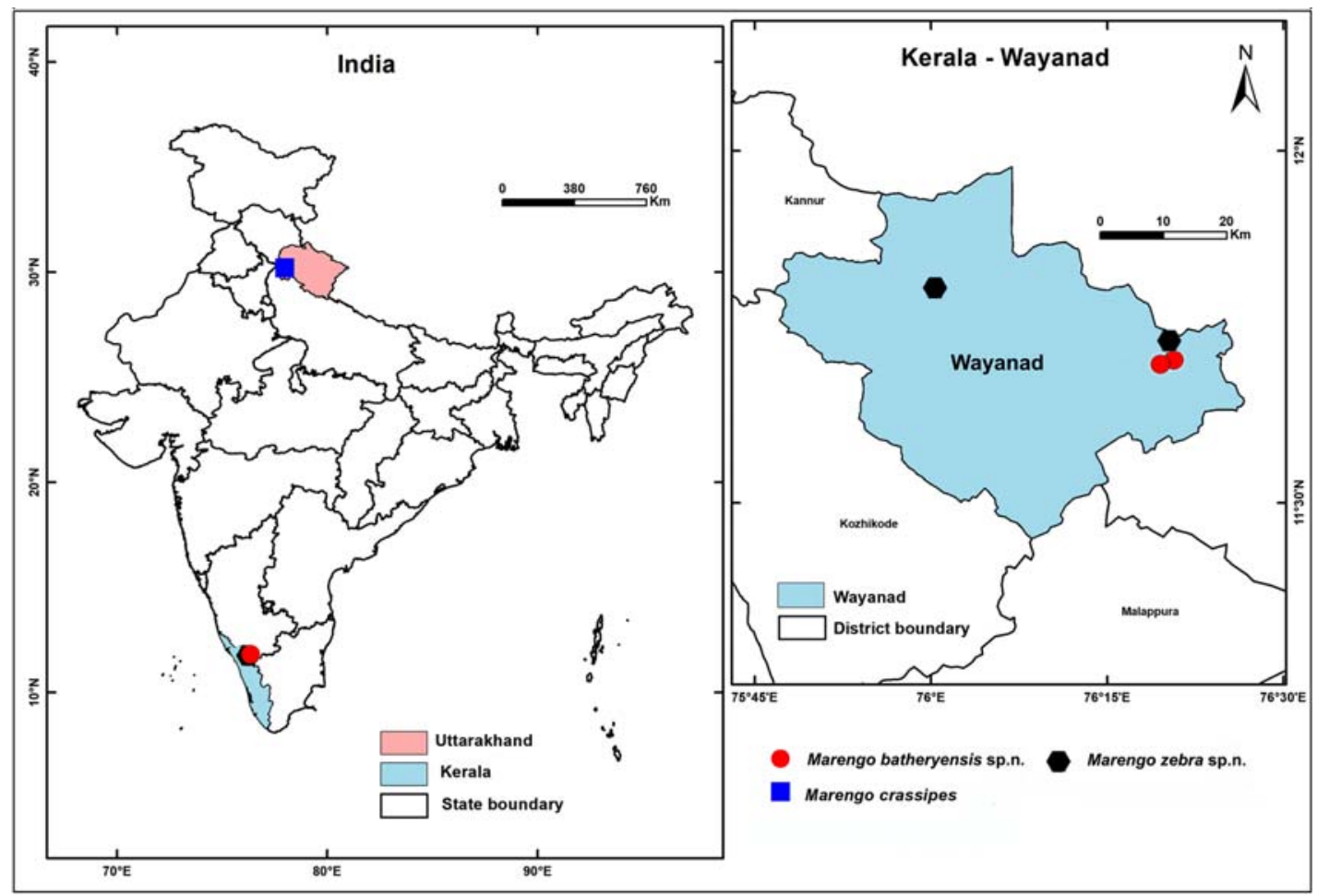

Map. Collecting localities of Marengo species in India. Карта. Точки сбора видов Marengo в Индии.

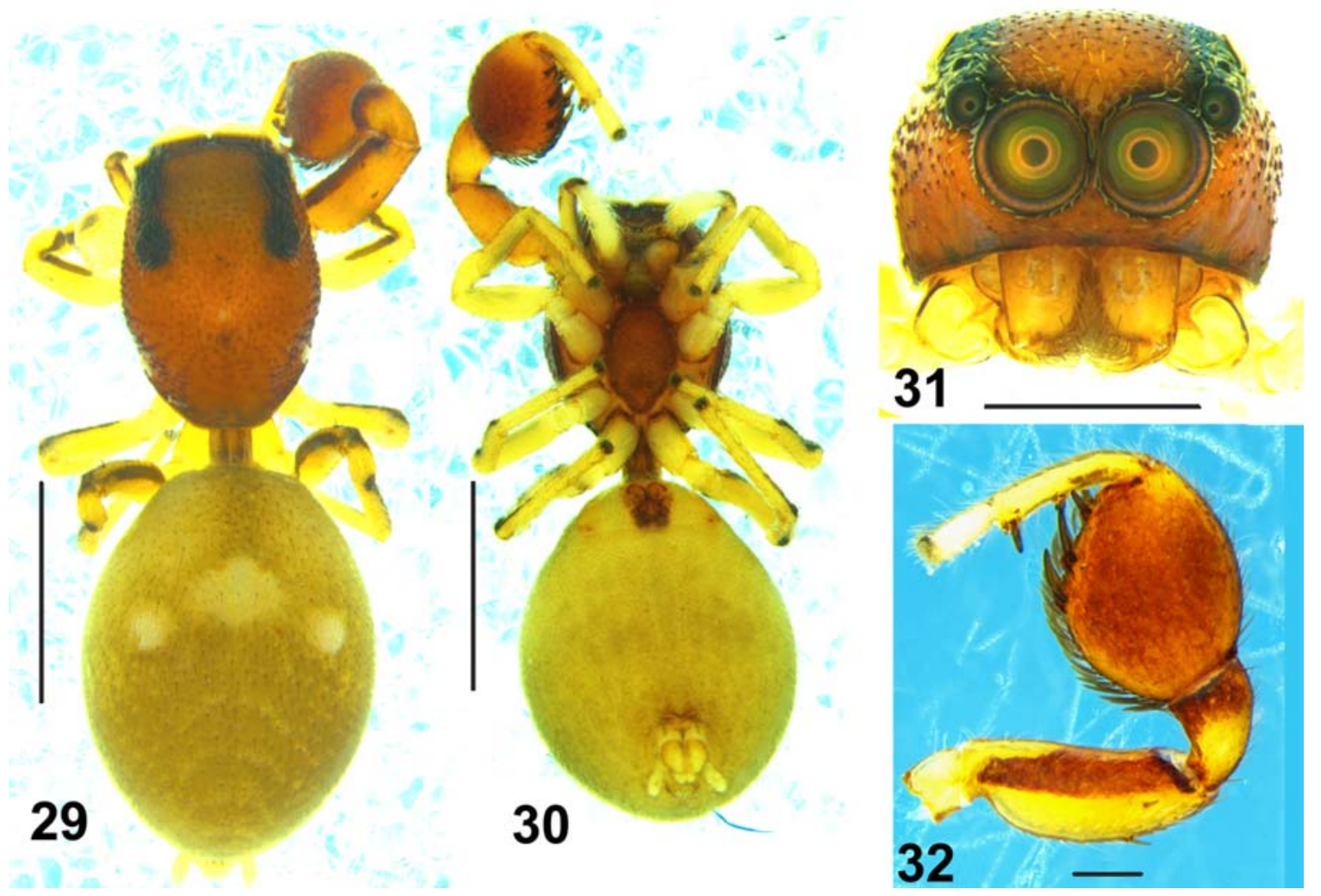

Figs 29-32. Marengo batheryensis sp.n., holotype female: 29 - general appearance, dorsal view; 30 - ditto, ventral view; 31 carapace, frontal view; 32 - right leg I, prolateral view. Scale bars: $1 \mathrm{~mm}(29,30), 0.5 \mathrm{~mm}(31), 0.2 \mathrm{~mm}(32)$.

Рис. 29-32. Marengo batheryensis sp.n., самка-голотип: 29 - общий вид, сверху; 30 - тоже, снизу; 31 - головогрудь, вид спереди; 32 - правая нога 1, вид спереди-сбоку. Масштаб: 1 мм (29, 30), 0,5 мм (31), 0,2 мм (32). 


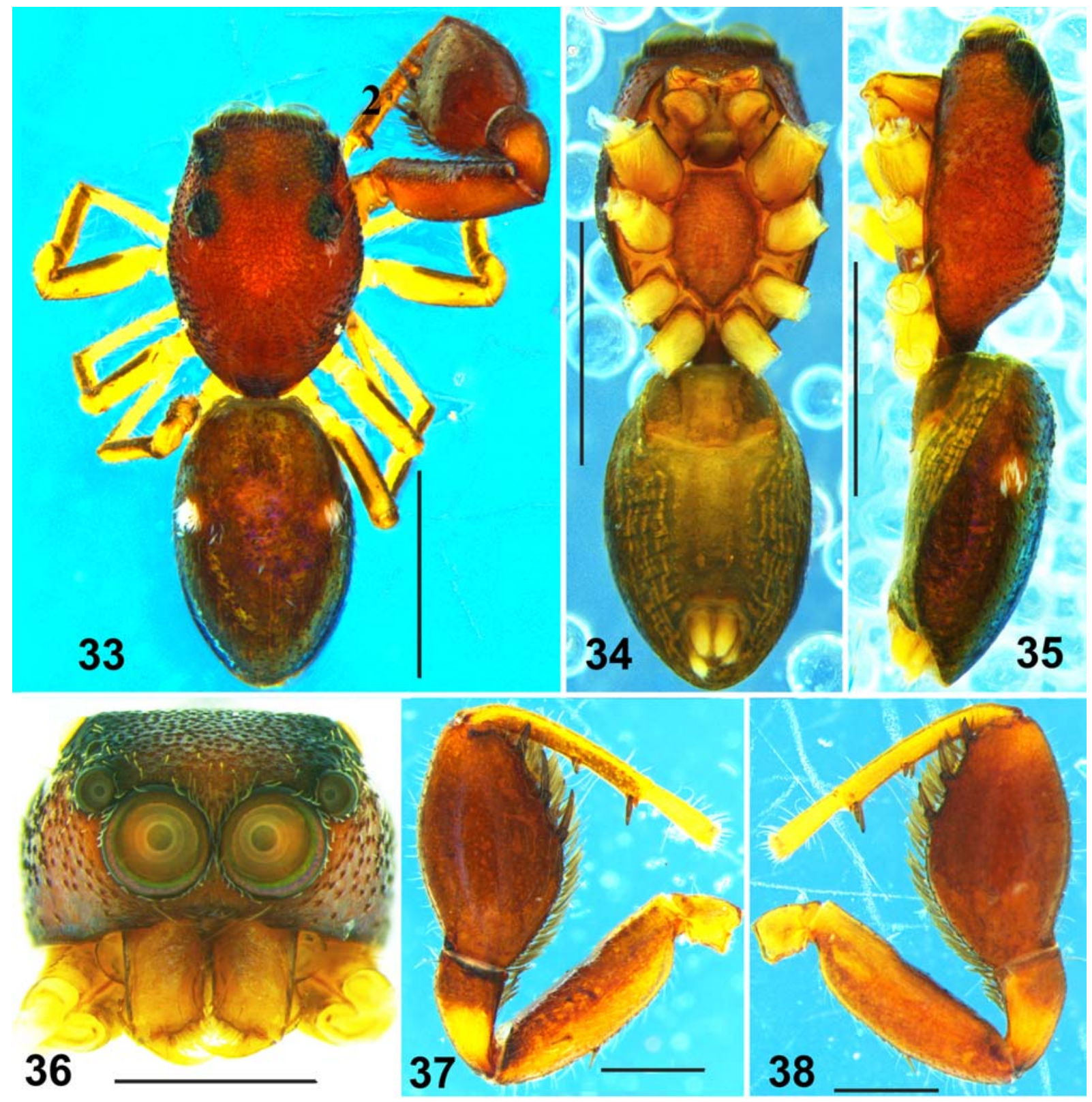

Figs 33-38. Marengo batheryensis sp.n., paratype male: 33 - general appearance, dorsal view; 34 - ditto, ventral view; 35 - ditto, lateral view; 36 - carapace, frontal view; 37 - left leg I, prolateral view; 38 - ditto, retrolateral view. Scale bars: $1 \mathrm{~mm}(33-35)$, $0.5 \mathrm{~mm}$ (36), $0.4 \mathrm{~mm}(37,38)$.

Рис. 33-38. Marengo batheryensis sp.n., самец-паратип: 33 - общий вид, сверху; 34 тоже, вид снизу; 35 - тоже, вид сбоку; 36 - головогрудь, вид спереди; 37 - левая нога 1, вид спереди-сбоку; 38 - то же, вид сзади-сбоку. Масштаб: 1 мм (33-35), 0,5 мм (36), 0,4 мм $(37,38)$.

AMEs (Fig. 33); chelicerae yellowish brown, frontal face slightly sloping retrolaterally, pro- and retromargins with two teeth (Fig. 36); endites yellowish brown; sternum light reddish brown (Fig. 34). Abdomen slightly shorter and linear with a dorsal scutum; dorsum glossy, greenish brown, with violet tint, without wide inverted V-shaped white bands (Figs 33, 35); venter light brown, medially with a pair of creamy dot lines, laterally with light yellowish longitudinal lines, intercepted by dark brown transverse lines (Figs 34, $35)$. Spinnerets creamy white, covered with white and light brown hairs (Fig. 34). Leg I dark reddish brown (Figs 37,
38). Palp as shown in Figs 27-28, 39-41: cymbium light yellow, tegulum yellowish brown, other segments light brown; tibia short, RTA short, directed disto-retrolaterad, narrowing towards the distal end, with a dark brown subacute tip (Figs 27, 41); cymbium oval, distally truncate with an excavated tip, tuft of setae on the truncated region (Figs 27, 39); tegulum bilobed, almost rectangular at ventral view (Figs 28, 39); embolic region damaged (Figs 27, 40).

FEMALE (holotype; Figs 18-19, 24-26, 29-32). Measurements: body length 3.24 . Carapace length 1.25 , width (at the middle) 0.90, height at PLE 0.55. Abdomen length 

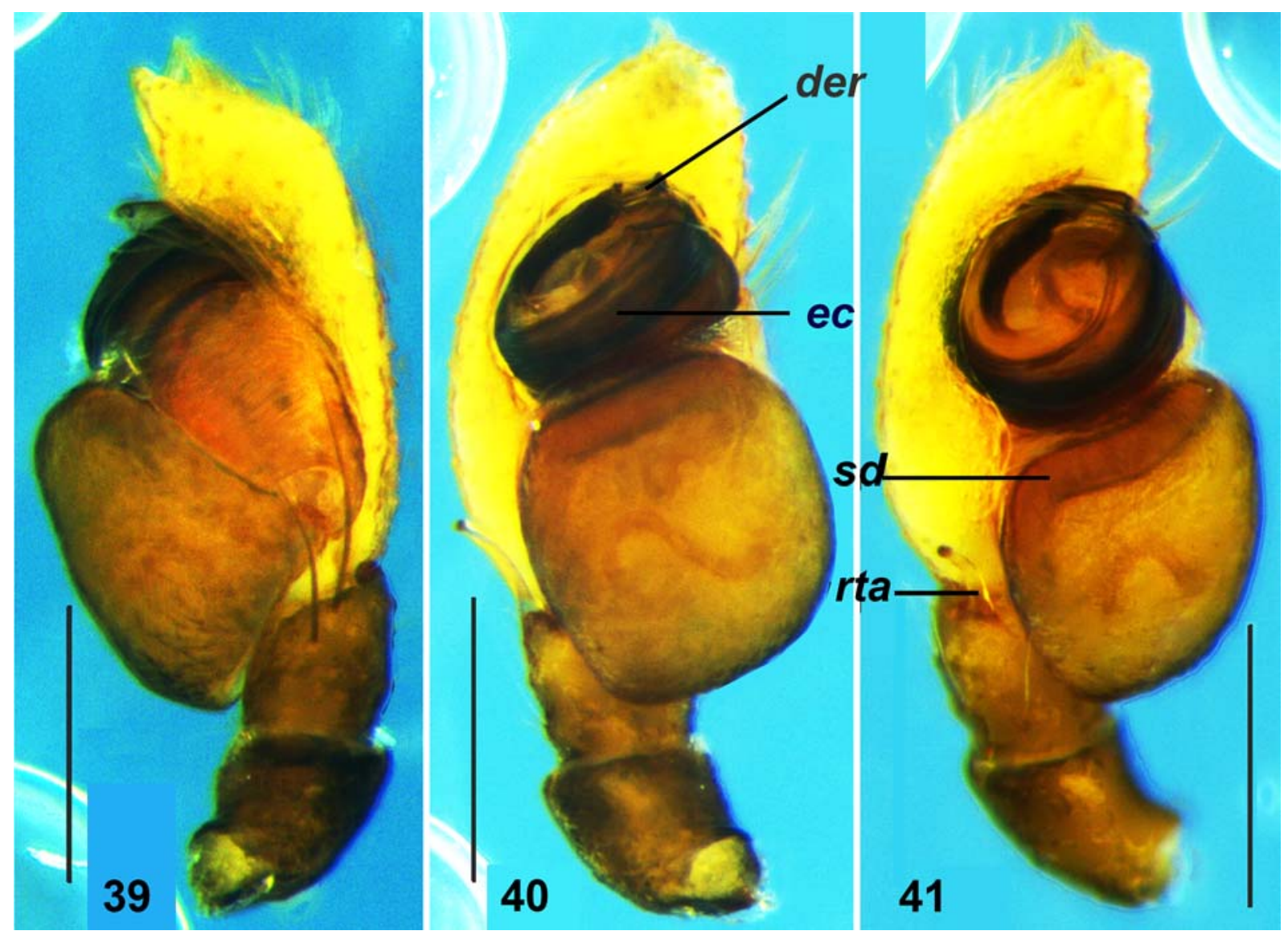

Figs 39-41. Right male palp of Marengo batheryensis sp.n.: 39 - prolateral view; 40 - ventral view, 41 - retrolateral view. Scale bars: $0.2 \mathrm{~mm}$.

Рис. 39-41. Правая пальпа самца Marengo batheryensis sp.n.: 39 - вид спереди-сбоку; 40 - вид снизу, 41 - вид сзади-сбоку. Масштаб: 0,2 мм.

1.84, width (at the middle) 1.33. Ocular area length 0.57 Eye diameters: AME 0.27, ALE 0.12, PME 0.04, PLE 0.12. Eye interdistances: PME-PME 0.57, ALE-ALE 0.48, PMEPLE 0.14, PLE-PLE 0.59, ALE-PME 0.09. Clypeus height 0.11. Length of chelicera 0.24. Palp and leg measurements: palp $0.77[0.30,0.10,0.13,0.24]$, leg I $2.21[0.64,0.32$, $0.64,0.39,0.22]$, II 1.58 [0.50, 0.19, 0.36, 0.30, 0.23], III $1.51[0.48,0.17,0.33,0.31,0.22]$, IV $1.71[0.60,0.22$, $0.37,0.30,0.22]$. Leg formula: 1423 . Spination. Palp: spineless. Legs: femur I do $1 \mathrm{pl} 1$, II do 1, III-IV pl 1; patellae IIV spineless; tibia I rlv 3 plv 3, II-IV spineless; metatarsi I rlv 3 plv 3, II-IV spineless; tarsi I-IV spineless. Carapace, oval, light reddish brown, raised at the centre, covered with white setae situated on minute elevations, with indistinct dark patches just behind AMEs, and white lateral spots in the thorax (Fig. 29); carapace margin with narrow brown lines; eyes surrounded by dark rings; clypeus low, subvertical, clothed with white setae (Fig. 31); chelicerae light yellowish brown, sub-vertical, with white and brown setae, retrolateral cheliceral margins slightly diverging, pro- and retromargins with three teeth, fangs short, light yellowish brown (Fig. 31); endites light yellow, longer than wide, with grey hairs on inner margins, endite margins with dark brown lines (Fig. 30). Labium light brown, subtriangular, with a dull white tip (Fig. 30). Sternum oval, light reddish brown, covered with white hairs, sternal margins dark brown (Fig
30). Pedicel light reddish brown. Abdomen ovoid, light ashy brown, covered with white setae; dorsum two pairs of sigilla and three white spots forming a wide triangle at the middle, which is covered with a tuft of white setae, the rear half of dorsum with four inverted V-shaped white stripes (Fig. 29); venter light grey, medially with a pair of light brown dotted lines (Fig. 30). Spinnerets light yellowish brown, covered with brown hairs (Fig. 30). Leg I light reddish brown, with lanceolate setae on ventral side of tibia and patella, femur I slender (Figs 32), other leg segments light yellowish. All legs with prolateral longitudinal black stripes on femora, patellae and tibiae, tarsal claws with nine teeth. Epigyne as shown in Figs 18-19, 24-26: epigyne yellowish brown, covered with long white hairs (Fig. 18); copulatory openings at the middle of the epigyne, leading to highly convoluted insemination ducts and entering the spermathecae posteriorly (Figs 18-19, 24-26); spermathecae light brown, located at the posterior end of the epigyne, left spermatheca Sshaped and right one L-shaped (Figs 19, 26); fertilization ducts moderately long, directed anteriad and located at the anterior region of the spermathecae (Figs 19, 26).

REMARKS. We have collected both sexes of Marengo batheryensis sp.n. from the same locality and are confident that they are conspecific. Unfortunately, the collected male has only the right palp with the damaged embolus; however, we have included its description in the species account. 
Acknowledgements. The authors are grateful to Dr Mathew Paul Ukken, the Principal of the Christ College (Autonomous), Irinjalakuda, Kerala, for providing us with the facilities for undertaking this study. Thanks to Ms. Sruthi $\mathrm{R}$., for collecting the female specimen of $M$. batheryensis from Wayanad. We are thankful to the Principal Chief Conservator of Forests, Kerala, for issuing the collecting permit. Many thanks are due to Mr Alex C. J. of the Kerala Forest Research Institute, Thrissur, Kerala for preparing the distribution map. The authors are grateful to Mr Dhanesh Kumar P., Wildlife Warden, and the field staff of the Wayanad Wildlife Sanctuary, especially to Mr Krishnadas K. Rajan, Assistant Wildlife Warden, Mr Suresh Thenarambath, Forester and $\mathrm{Mr} \mathrm{Appu}$, Field watcher for the hospitality and field support. This study was funded by the Science \& Engineering Research Board (SERB) DST, New Delhi, under the Young Scientist Research Project: No. SB/YS/LS86/2013. We are grateful to Dr Dmitry V. Logunov of The Manchester Museum (UK) for his editorial help and to anonymous reviewers for their help in improving the ms.

\section{References}

Benjamin S.P. 2004. Taxonomic revision and phylogenetic hypothesis for the jumping spider subfamily Ballinae (Araneae, Salticidae) // Zoological Journal of the Linnaean Society. Vol.142. P.1-82.

Benjamin S.P. 2006. The male of Marengo nitida with the description of $M$. rattotensis new species from Sri Lanka (Araneae: Salticidae) // Zootaxa. Vol.1326. P.25-36.

Bosselaers J., Jocqué J. 2000. Studies in Corinnidae: transfer of four genera and description of the female of Lessertina mutica Lawrence 1942 // Tropical Zoology. Vol.13. P.305-325.

Gupta N., Siliwal M. 2012. A checklist of spiders (Arachnida: Araneae) of Wildlife Institute of India campus, Dehradun, Uttarakhand, India // Indian Journal of Arachnology. Vol.1. No.2. P.73-91.

Peckham G.W., Peckham E.G. 1892. Ant-like spiders of the family Attidae // Occasional Papers of the Natural History Society of Wisconsin. Vol. 2. No.1. P.1-84.

Reiskind J. 1969. The spider subfamily Castianeirinae of North and Central America (Araneae, Clubionidae) // Bulletin of the Museum of Comparative Zoology. Vol.138. P.163-325.

Wanless F.R. 1978. A revision of the spider genus Marengo (Araneae: Salticidae) //Bulletin of the British Museum of Natural History (Zool.). Vol.33. P.259-278.

WSC 2019. World Spider Catalog. Natural History Museum Bern, online at: http://wsc.nmbe.ch, version 19 (accessed on 27th January 2019). 